\title{
PENGARUH STRATEGI PEMBELAJARAN DAN KOMUNIKASI INTERPERSONAL TERHADAP HASIL BELAJAR BAHASA ARAB
}

\author{
Rina Feriana \\ Guru MAN 1 Stabat, Sumatera Utara \\ rina_feriana@yahoo.com
}

\begin{abstract}
Abstrak: Penelitian ini bertujuan (1) untuk mengetahui hasil belajar bahasa Arab siswa yang diajar dengan menggunakan strategi pembelajaran komunikatif lebih tinggi daripada siswa yang diajar dengan menggunakan strategi pembelajaran struktural, (2) untuk mengetahui hasil belajar bahasa Arab siswa yang komunikasi interpersonal tinggi lebih tinggi daripada siswa yang komunikasi interpersonal rendah, (3) untuk mengetahui interaksi antara strategi pembelajaran dengan komunikasi interpersonal terhadap hasil belajar bahasa Arab. Metode penelitian menggunakan metode quasi eksperimen dan Teknik analisis data menggunakan ANAVA dua jalur. Temuaan penelitian menunjukkan bahwa (1) hasil belajar bahasa Arab siswa yang diajar dengan strategi pembelajaran komunikatif lebih tinggi dari hasil belajar siswa yang diajar dengan strategi pembelajaran struktural, (2) hasil belajar bahasa Arab siswa komunikasi interpersonal tinggi lebih tinggi dari hasil belajar siswa komunikasi interpersonal rendah, (3) terdapat interaksi antara strategi pembelajaran dan komunikasi interpersonal terhadap hasil belajar bahasa Arab. Berdasarkan hasil penelitian disimpulkan adanya interaksi antara strategi pembelajaran dengan komunikasi interpersonal terhadap hasil belajar bahasa Arab, untuk itu disarankan agar guru dapat menggunakan strategi pembelajaran yang disesuaikan dengan ciri siswa termasuk komunikasi interpersonal sebagai upaya meningkatkan hasil belajar siswa.
\end{abstract}

Kata Kunci: strategi komunikatif, komunikasi interpersonal, hasil belajar, bahasa arab.

Abstract: This research was aimed to find out: (1) the achievement in Arab langunge with communicative strategy is higher than structural instructional strategy (2) the achievement of Arab langunge high interpersonal communication students 'is higher than students' with low interpersonal communication, (3) interaction between instructional strategy and interpersonal communication on the students' achievement in Arab language. The research method used quasiexperiment. Technique of analyzing data used ANOVA of two ways. The finding of the research showed that: (1) the students' achievement in Arab languange that taught by communicative strategy is higher than the students' achievement that taught by structural strategy, (2) the students' achievement in Arab language students' with high Interpersonal communication is higher than students' with low interpersonal communication, (3) be found interaction between instructional strategy and the Interpersonal communiaction on the students' achievement in Arab language. Summary this research found interaction between instructional strategy and the interpersonal communication on the students' achievement in Arab language, for teacher must taugh instructional strategy find with students' charecteristic imploying the interpersonal communication for students' achievement.

Keywords: communicative strategy, interpersonal communication, learning outcomes, Arab language

\section{PENDAHULUAN}

Bahasa merupakan alat komunikasi, komunikasi adalah pengiriman atau penerimaan pesan atau berita antara dua orang atau lebih sehingga pesan yang dimaksud dapat dipahami. Sebagai alat komunikasi, bahasa mempunyai fungsi sosial dan fungsi kultural. Bahasa sebagai fungsi sosial adalah sebagai alat perhubungan antar anggota masyarakat. Sedangkan dari aspek kultural bahasa merupakan sarana pelestarian budaya dari satu generasi ke generasi berikutnya.

Sebagai mata pelajaran yang wajib diikuti siswa madrasah, bahasa Arab merupakan mata pelajaran wajib yang diarahkan untuk mendorong, membimbing, mengembangkan 
dan membina kemampuan bahasa Arab pada siswa madrasah mulai tingkat ibtidiyah (MI) setingkat sekolah dasar (SD), tingkat Tsanawiyah (MTs) setingkat sekolah menengah pertama (SMP), maupun madrasah aliyah (MA) setingkat sekolah menengah (SMA). Bahasa Arab adalah bahasa yang dipakai dalam Al-qur'an. Dengan didukung beberapa doktrin ajaran Islam, bahasa Arab terus mempengaruhi masyarakat muslim di berbagai tempat. Misalnya doktrin bahwa Alqur'an harus ditulis dan dibaca sesuai dengan bahasa aslinya. Terjemahan Al-qur'an dipandang sebagai sesuatu di luar Al-qur'an itu sendiri. Doktrin pendukung lainnya adalah berbagai ucapan ritual ibadah hanya dianggap sah jika dilakukan dalam bahasa Arab, maka doktrin-doktrin seperti ini telah memacu motivasi masyarakat muslim untuk mempelajari dan menguasai bahasa Arab sejak dini agar kelak menjadi muslim yang baik.

Sama seperti halnya bahasa lain, dalam mempelajari bahasa Arab tercakup empat keterampilan berbahasa yang harus dikuasai siswa, yaitu mendengarkan, membaca, berbicara, dan menulis. Keempat keterampilan ini dalam pelaksanaannya diharapkan dapat disampaikan secara terpadu sehingga dapat meningkatkan kemampuan siswa dalam berkomunikasi dalam bahasa Arab secara lisan dan tertulis. Seperti yang dikemukakan Nurhadi (2004: 79) yang menyatakan bahwa penguasaan bahasa Indonesia dan bahasa asing termasuk bahasa Arab diharapkan membantu siswa mengenal dirinya, budayanya, dan budaya orang lain, serta mampu mengemukakan gagasan dan perasaan, berpartisipasi dalam masyarakat yang menggunakan bahasa tersebut, membuat keputusan yang bertanggung jawab pada tingkat pribadi dan sosial, menemukan serta menggunakan kemampuan-kemampuan analitis dan imaginatif yang ada dalam dirinya. Sumarsono (2004: 32) menyatakan bahasa adalah alat untuk mengungkapkan pikiran dan perasaan manusia. Artinya, bahasa baru ada kalau sesuatu yang ingin diungkapkan, yaitu pikiran atau perasaan. Dengan kata lain, pikiran mempengaruhi bahasa.

Selanjutnya Romdani (2003: 56) menyatakan bahwa mata pelajaran Bahasa Arab di madrasah aliyah berfungsi sebagai alat komunikasi disamping sebagai bahasa Agama dan ilmu pengetahuan. Mata pelajaran bahasa Arab merupakan mata pelajaran pokok di madrasah, yang selain fungsi-fungsi di atas, juga berfungsi sebagai alat pengembangan diri peserta didik dalam bidang komunikasi, dan ilmu pengetahuan.

Menurut Bruner (dalam Sudjana, 2001) belajar yang terbaik haruslah merupakan proses berpikir, dan berpikir pada hakikatnya merupakan proses kognitif, sehingga manusia membedakan, memilih, dan menentukan objek, serta kemampuan untuk mengkonstruksi kembali informasi yang telah diterima. Sedangkan hakikat belajar menurut Dahar (1989) adalah adanya perubahan tingkah laku. Perubahan tingkah laku sebagai hasil belajar ditunjukkan dengan berbagai aspek seperti perubahan pengetahuan, pemahaman, persepsi, motivasi, dan gabungan dari aspek-aspek tersebut. Sependapat dengan hal ini Tirtarahardja dan Sula (2000) mengemukakan bahwa belajar adalah sebagai aktivitas pengembangan diri melalui pengalaman, bertumpu pada kemampuan pada diri siswa di bawah bimbingan guru. Belajar merupakan perubahan seluruh tingkah laku individu secara bertahap yang relatif menetap sebagai hasil pengalaman dan interaksi dengan lingkungan yang melibatkan proses kognitif.

Fudyartanta (2002) merangkum berbagai pendapat para ahli psikologi tentang pengertian belajar antara lain: (a) belajar adalah perubahan tingkah laku melalui pengalaman dan latihan, (b) belajar adalah suatu proses aktif yang perlu dirangsang dan dibimbing ke arah hasil-hasil yang diinginkan, (c) belajar adalah perubahan yang dialami secara relatif abadi dalam tingkah laku yang merupakan suatu fungsi dari tingkah laku sebelumnya, (d) belajar adalah membawa perubahan-perubahan dalam tingkah laku dari organisme dan (e) belajar sebagai perubahan relatif yang permanen dalam potensialitas. Dari pengertian belajar tersebut dapat dinyatakan bahwa pada hakikatnya belajar adalah proses perubahan tingkah laku atau kecakapan manusia. Perubahan tingkah laku ini bukan disebabkan oleh proses pertumbuhan yang bersifat fisiologis atau proses kematangan. Perubahan yang terjadi karena proses belajar yang dialami oleh peserta didik. Maka hasil belajar siswa baik berupa perubahan pengetahuan, keterampilan, dan sikap, sangat tergantung pada bagaimana individu berinteraksi dengan lingkungannya termasuk guru.

Untuk mengetahui keberhasilan seseorang dalam belajar adalah dari hasil 
belejar yang diperolehnya. Hasil belajar menurut Bloom yang dikembangkan Anderson (2001) dibagi dalam tiga kawasan yaitu kognitif, afektif, dan psikomotor. Kawasan kognitif terdiri dari 6 (enam) jenis perilaku yaitu : (1) ingatan, mencakup kemampuan mengingat tentang hal yang telah dipelajari dan tersimpan dalam ingatan, (2) pemahaman, mencakup kemampuan menangkap arti dan makna dari pesan, pembicaraan, tulisan, dan grafik, (3) penerapan, mencakup kemampuan menerapkan atau menggunakan prosedur untuk menghadapi situasi yang baru, (4) analisis, mencakup kemampuan merinci suatu kesatuan ke dalam bagian-bagian sehingga struktur keseluruhan dapat dipahami dengan baik, (5) evaluasi, mencakup kemampuan membentuk pendapat tentang beberapa hal berdasarkan kriteria dan standar tertentu, dan (6) kreativitas, mencakup kemampuan menggabungkan beberapa bagian menjadi suatu bentuk yang koheren atau berfungsi secara menyeluruh, mengorganisasikan bagian-bagian menjadi sebuah pola atau struktur yang baru.

Romizowski (1981) menyatakan bahwa hasil belajar diperoleh dalam bentuk pengetahuan dan keterampilan. Pengetahuan dikelompokkan pada empat kategori yaitu: (1) fakta, merupakan pengetahuan tentang objek nyata, asosiasi dari kenyataan, dan informasi verbal dari suatu objek, peristiwa atau manusia; (2) konsep, merupakan pengetahuan tentang seperangkat objek konkrit atau definisi; (3) prosedur, merupakan pengetahuan tentang tindakan demi tindakan yang bersifat linier dalam mencapai suatu tujuan; dan (4) prinsip, merupakan pernyataan mengenai hubungan dari dua konsep atau lebih. Sedangkan hasil belajar dalam bentuk keterampilan juga dikelompokkan dalam empat kategori yaitu: (1) keterampilan kognitif, merupakan keterampilan seseorang dalam menggunakan pikiran untuk mengambil keputusan atau memecahkan masalah; (2) akting, yaitu keterampilan fisik atau teknik seperti olah raga atau terampil dalam mengerjakan sesuatu; (3) reaksi, merupakan keterampilan bereaksi terhadap suatu situasi dalam arti nilai-nilai emosi dan perasaan dengan orang lain untuk mencapai suatu tujuan seperti komunikasi, persuasi, dan pendidikan.

$$
\text { Sedangkan }
$$$$
\text { Reigeluth }
$$

menyatakan hasil pembelajaran harus memiliki efektivitas, efisiensi dan daya tarik. Efektivitas diukur dari tingkat pencapaian hasil belajar yang diperoleh oleh peserta didik, baik secara kualitas maupun kuantitas. Secara kualitas hasil belajar menunjukkan kebermaknaan isi bahan yang dipelajari dalam kehidupan sehari-hari, sedangkan kuantitas menunjukkan jumlah variasi hasil belajar yang dapat dicapai oleh pebelajar. Efesiensi diukur berdasarkan waktu yang dibutuhkan pebelajar untuk belajar, dalam arti semakin sedikit waktu yang dibutuhkan pebelajar untuk memahami isi materi pelajaran, maka semakin efisien hasil belajar yang diperoleh. Sedangkan daya tarik diukur dari ada tidaknya kecenderungan pebelajar termotivasi untuk belajar lebih lanjut dalam arti mengembangkan wawasan berdasarkan hasil belajar yang telah diperoleh.

Untuk mengetahui apakah peserta didik telah menguasai sejumlah kompetensi sebagai hasil dari belajar, perlu dilakukan evaluasi. Evaluasi digunakan sebagai alat kontrol untuk mengetahui sejauh mana seseorang telah mencapai hasil belajar. Menurut Gronlund (1985) untuk melihat hasil belajar yang telah dicapai siswa, setelah siswa melakukan belajar dapat dilakukan melalui tes atau bentuk evaluasi yang diberikan secara periodik. Syah (1996) mengemukakan tes hasil belajar adalah alat ukur yang digunakan untuk menentukan taraf keberhasilan suatu program pengajaran.

Pengelolaan pembelajarn mengacu kepada suatu upaya untuk mengatur aktivitas pembelajaran berdasarkan konsep dan prinsip pembelajaran yang tidak terlepas dari prinsipprinsip belajar bagi siswa. Hal ini mencakup (1) perhatian dan motivasi, (2) keaktifan, (3) keterlibatan langsung/ berpengalaman, (4) pengulangan, (5) tantangan, (6) balikan dan penguatan, serta (7) perbedaan individual (Dimyati dan Mudjiono, 2002).

Program pembelajaran bahasa Arab secara umum memiliki tujuan agar para peserta didik berkembang dalam hal (1) kemampuan mendengarkan, berbicara, membaca, dan menulis secara baik, (2) berbicara secara sederhana tapi efektif dalam berbagai konteks untuk menyampaikan informasi, pikiran dan perasaan, serta menjalin hubungan sosial dalam bentuk kegiatan yang beragam, interaktif dan menyenangkan, (3) menafsirkan isi berbagai bentuk teks tulis pendek sederhana dan merespon dalam bentuk kegiatan yang beragam, interaktif, dan menyenangkan (4) menulis kreatif meskipun pendek sederhana berbagai bentuk teks untuk menyampaikan informasi, mengungkapkan pikiran dan perasaan, (5) menghayati dan menghargai karya sastra, (6) 
kemampuan untuk berdiskusi dan menganalisis teks secara kritis, (7) perbendaharaan kata Arab fushha sebanyak 1500 kosa kata lebih dalam berbagai bentuk kata dan pola kalimat yang diprogramkan meliputi tema tentang kegiatan sehari-hari, dan kajian keislaman (Departemen Pendidikan Nasional, 2004).

Dengan sejumlah penguasaan kompetensi berbahasa sesuai kaidah dan pelafalan yang benar sebagaimana tersebut di atas siswa MA diharapkan mampu berbahasa Arab secara reseftif maupun ekspresif. Jadi belajar bahasa Arab bukan lagi mempelajari bahasa sebagai sistem otonom, yang berdiri sendiri, melainkan bahasa dalam hubungan dengan peranan komunikatifnya dalam pemakaian, sehingga orang yang mempelajarinya dapat berpartisipasi dalam proses interaksi penggunaan bahasa.

Namun pada kenyataannya kemampuan siswa dalam menguasai bahasa, khususnya bahasa Arab masih jauh dari apa yang diharapkan, selain tidak dapat berkomunikasi dengan menggunakan bahasa secara efektif, prestasi belajar bahasa siswapun masih rendah. Ketidakmampuan siswa dalam menguasai bahasa, termasuk bahasa Arab disebabkan oleh banyak faktor. Seperti yang dikemukakan Susanti (2002: 4) ada beberapa faktor penyebab prestasi belajar bahasa Arab siswa rendah, diantaranya karena kemampuan guru seringkali kurang memadai untuk memenuhi tuntutan siswa terutama siswa-siswa yang punya kemampuan tinggi dalam berbahasa dan punya sarana belajar yang lebih canggih dari pada gurunya sendiri, sistem belajar mengajar sering bersifat monoton, kurang bervariasi dan kurang menarik sehingga siswa menjadi bosan, tidak tertarik untuk belajar. Bahkan menurut Sanjaya (2007: 57) pembelajaran mata pelajaran bahasa tidak diarahkan untuk mengembangkan kemampuan berkomunikasi, karena yang dipelajari lebih banyak bahasa sebagai ilmu bukan sebagai alat komunikasi.

Fakta di atas diperkuat temuan Muhaiban (2006: 11) yang mengungkapkan bahwa pembelajaran bahasa Arab di Indonesia menghadapi berbagai problematika. Menurut Muhaiban, problematika pembelajaran bahasa Arab tersebut setidaknya menyangkut 3 aspek penting, yaitu aspek guru, aspek siswa, dan aspek media pembelajaran. Problematika yang diakibatkan oleh guru muncul karena lemahnya kompetensi guru dalam pembelajaran bahasa Arab dan terbatasnya jumlah guru yang memiliki kompetensi berbahasa Arab secara memadai, terutama kemampuan berbicara (takallum) dan menulis (kitabah). Di samping itu juga karena terbatasnya jumlah guru yang memiliki kompetensi akademis sebagai guru bahasa Arab. Problematika yang terkait dengan siswa diakibatkan oleh beberapa hal antara lain latar belakang pendidikan, motivasi, dan tujuan belajar bahasa Arab.

Adapun menurut Kamaluddin (2005: 5) problem pembelajaran bahasa Arab di Indonesia secara umum adalah proses belajar mengajar (PBM) yang kurang menarik dan cenderung membosankan. Hal ini disebabkan karena sistim pengajarannya yang cenderung dimulai dari gramatika-terjemah atau tata bahasa (qawa'id) dan mengabaikan aspek kemahiran yang lainnya seperti kemahiran menyimak, berbicara dan menulis. Rendahnya kemampuan siswa dalam berbahasa Arab merupakan masalah yang banyak ditemui di berbagai MA di Indonesia. Rendahnya prestasi belajar siswa dalam mata pelajaran bahasa, khususnya bahasa Arab juga terjadi di madrasah aliyah negeri (MAN) Binjai dan MAN Stabat.

Rendahanya rata-rata hasil belajar di MAN Binjai disebabkan tidak tercapainya standar kelulusan untuk menguasai bahasa Arab di MAN Binjai yaitu jika siswa telah memperoleh nilai minimal 70. Sama halnya dengan MAN Binjai pada MAN 1 Stabat Kabupaten Langkat, nilai rata-rata hasil belajar siswa juga tergolong rendah karena tidak mencapai nilai minimal ketuntasan belajar untuk mata pelajaran bahasa Arab di sekolah tersebut, yaitu 65 .

Munculnya permasalahan ini sebenarnya disebabkan antara lain karena kurang bervariasinya strategi pembelajaran yang digunakan guru. Di kelas, siswa seringkali hanya diberi teori-teori, kaidah-kaidah dan hukum-hukum bahasa, bukannya aplikasi kaidah-kaidah dan hukum-hukum itu dalam penggunaan praktisnya sehingga siswa tidak merasakan manfaat belajar bahasa Arab. Sebagian besar guru dalam mengajar bahasa Arab di MAN Binjai dan MAN 1 Stabat masih menggunakan komunikasi satu arah, yaitu guru hanya bertindak sebagai pemberi ilmu pengetahuan tanpa memperhatikan aspek kebermaknaan pembelajaran, sehingga siswa kurang menyukai pelajaran bahasa Arab karena dalam kegiatan pembelajaran yang diikuti dirasakan tidak memberi makna yang berarti pada siswa. 
Dalam meningkatkan hasil belajar keaktifan siswa sangat diperlukan dalam pembelajaran dan guru harus dapat memilih dan mengembangkan pembelajaran sesuai dengan kondisi yang diprediksikan dapat meningkatkan hasil belajar siswa.

Kemampuan guru dalam menerapkan strategi pembelajaran yang tepat sangat penting untuk mencapai keberhasilan pembelajaran. Dengan menerapkan strategi pembelajaran yang tepat diharapkan akan meningkatkan keterlibatan siswa dalam kegiatan pembelajaran. Banyak strategi pembelajaran yang dapat digunakan untuk menarik perhatian siswa agar aktif dalam pembelajaran khususnya dalam hal mempelajari bahasa Arab. Salah satu strategi tersebut adalah strategi komunikatif yang lebih mengutamakan kelancaran berkomunikasi atau penggunaan bahasa. Strategi komunikatif berorientasi pada fungsi bahasa sebagai alat komunikasi. Melalui strategi komunikatif dalam mata pelajaran bahasa Arab diharapkan siswa mampu menggunakan sejumlah kemampuan dalam bahasa Arab ketika berkomunikasi di tengahtengah lingkungan sosial masyarakat. Siswa diharapkan dapat melakukan komunikasi interpersonal dengan baik sehingga prinsipprinsip komunikasi dapat dipenuhi secara baik dan benar, dalam belajar bahasa Arab, komunikasi interpersonal adalah bagian yang penting dalam upaya melakukan kegiatan komunikasi. Dengan strategi pembelajaran yang lebih variatif diharapkan dapat meningkatkan komunikasi interpersonal siswa.

Rumusan masalah dalam penelitian ini antara lain (1) Apakah hasil belajar bahasa Arab siswa yang diajar dengan menggunakan strategi pembelajaran komunikatif lebih tinggi daripada hasil belajar siswa yang diajar dengan menggunakan strategi pembelajaran struktural?, (2) Apakah hasil belajar bahasa Arab siswa yang memiliki komunikasi interpersonal tinggi lebih tinggi daripada hasil belajar bahasa Arab siswa yang memiliki komunikasi interpersonal rendah?, (3) Apakah ada interaksi antara strategi pembelajaran dengan komunikasi interpersonal terhadap hasil belajar bahasa Arab?

\section{METODE}

Penelitian ini akan dilaksanakan di kelas X MAN Binjai dan MAN 1 Stabat. Populasi dalam penelitian ini adalah seluruh siswa kelas X MAN Binjai dan MAN 1 Satabat pada semester genap. Pada MAN Binjai terdiri dari 158 orang siswa.

Teknik pengambilan sampel dilakukan dengan teknik cluster random sampling, dari empat kelas yang telah terpilih sebagai sampel penelitian, selanjutnya melalui pengundian maka kelas X-1 MAN Binjai, dan X-4 MAN Binjai terpilih sebagai kelas yang akan diberi perlakuan dengan strategi pembelajaran struktural, sedangkan kelas X-2 MAN 1 Stabat dan kelas X-3 MAN 1 Stabat terpilih sebagai kelas yang diberi perlakuan dengan strategi pembelajaran komunikatif.

Desain penelitian yang digunakan adalah desain faktorial $2 \times 2$, seperti terlihat pada Tabel 1. yang mengelompokkan strategi Mind Map dengan strategi pembelajaran ekspositori terhadap gaya belajar visual dan gaya belajar kinestetik.

Tabel 1. Desain Faktorial 2 x 2

\begin{tabular}{|l|c|c|}
\hline $\begin{array}{l}\text { Strategi } \\
\text { Kembelajaran }(\mathrm{A})\end{array}$ & Komunikatif $\left(\mathrm{A}_{1}\right)$ & Struktural $\left(\mathrm{A}_{2}\right)$ \\
Interpersonal (B) & & \\
\hline Tinggi $\left(\mathrm{B}_{1}\right)$ & $\mathrm{A}_{1} \mathrm{~B}_{1}$ & $\mathrm{~A}_{2} \mathrm{~B}_{1}$ \\
\hline Rendah $\left(\mathrm{B}_{2}\right)$ & $\mathrm{A}_{1} \mathrm{~B}_{2}$ & $\mathrm{~A}_{2} \mathrm{~B}_{2}$ \\
\hline
\end{tabular}

Teknik pengumpulan data dalam penelitian ini adalah menggunakan tes untuk hasil belajar Gambar teknik mesin dan tes gaya belajar siswa. Tes hasil belajar berupa pertanyaan-pertanyaan dalam bentuk pilihan ganda dengan 4 (empat) pilihan jawaban pada mata pelajaran Gambar teknik mesin SMK Program keahlian teknik mesin yang meliputi materi ajar standar gambar teknik, memilih dan menentukan peralatan, 
perlengkapan dan media gambar sesuai dengan tujuan penggambaran, Macammacam penggaris, Satuan dasar dan skala gambar, sedangkan untuk mengelompokkan siswa atas gaya belajar visual maupun kinestetik dilaksanakan dengan tes gaya belajar menurut De Porter (2008).

Teknik analisis data dalam penelitian ini menggunakan analisis deskriptif dan analisis inferensial. Teknik analisis deskriptif dimaksudkan untuk mendeskripsikan data penelitian meliputi mean, median, standard deviasi dan kecenderungan data. Data yang telah diperoleh selanjutnya disajikan dalam bentuk tabel distribusi frekuensi dan histogram. Teknik analisis inferensial digunakan untuk menguji hipotesis penelitian dengan menggunakan teknik analisis varians (ANAVA) dua jalur. Untuk menggunakan ANAVA dua jalur perlu dipenuhi beberapa syarat yaitu: (1) data yang digunakan harus berdistribusi normal, untuk menguji normalitas data digunakan uji Liliefors, dan
(2) data harus memiliki varians populasi homogen, untuk menguji homogenitas varians digunakan uji F (Fisher) dan

Rumusan hipotesis statistik dalam penelitian ini adalah sebagai berikut:

a. Hipotesis pertama :

$$
\begin{array}{ll}
\text { Ho } & : \mu_{A 1} \leq \mu_{A 2} \\
\text { H1 } & : \mu_{A 1}>\mu_{A 2}
\end{array}
$$

b. Hipotesis kedua :

$$
\begin{array}{ll}
\text { Ho } & : \mu_{B 1} \leq \mu_{B 2} \\
\text { H1 } & : \mu_{B 1}>\mu_{B 2}
\end{array}
$$

c. Hipotesis ketiga :

$$
\text { Ho : } \mathrm{A} \times \mathrm{B}=0
$$

\section{HASIL PENELITIAN}

\begin{tabular}{|c|c|c|c|c|}
\hline \multirow{2}{*}{\multicolumn{2}{|c|}{$\begin{array}{c}\text { RINGKASAN } \\
\text { DATA } \\
\end{array}$}} & \multicolumn{2}{|c|}{ MODEL PEMBELAJARAN } & \multirow{2}{*}{ Total } \\
\hline & & Inkuiri & Masyarakat Belajar & \\
\hline \multirow{2}{*}{$\begin{array}{l}\text { Gaya } \\
\text { Belajar }\end{array}$} & Visual & $\begin{array}{c}\mathrm{n}_{1}=22 \\
\sum \mathrm{P}_{1}=576 \\
\sum \mathrm{X}_{1}{ }_{1}=15178 \\
\overline{\mathrm{X}}_{1}=26,23 \\
\mathrm{~s}^{2}{ }_{1}=5,79\end{array}$ & $\begin{array}{c}\mathrm{n}_{3}=21 \\
\sum \mathrm{P}_{3}=473 \\
\sum \mathrm{X}_{3}{ }_{3}=10775 \\
\overline{\mathrm{X}}_{3}=22,70 \\
\mathrm{~S}^{2}{ }_{3}=5,78\end{array}$ & $\begin{aligned} \mathrm{N}_{1,3} & =43 \\
\sum \mathrm{P}_{1,3} & =1049 \\
\sum \mathrm{X}_{1,3}^{2} & =25953 \\
\overline{\mathrm{X}}_{1,3} & =24,41 \\
\mathrm{~s}_{1,3}^{2} & =9,14\end{aligned}$ \\
\hline & Auditorial & $\begin{aligned} \mathrm{n}_{2} & =16 \\
\sum \mathrm{P}_{2} & =338 \\
\sum \mathrm{X}_{2} & =7230 \\
\overline{\mathrm{X}}_{2} & =21,00 \\
\mathrm{~s}_{2}{ }_{2} & =4,92\end{aligned}$ & $\begin{aligned} \mathrm{n}_{4} & =15 \\
\sum \mathrm{P}_{4} & =351 \\
\sum \mathrm{X}^{2}{ }_{4} & =8295 \\
\overline{\mathrm{X}}_{4} & =23,37 \\
\mathrm{~S}_{4}{ }_{4} & =5,41\end{aligned}$ & $\begin{array}{c}\mathrm{N}_{2,4}=31 \\
\sum \mathrm{P}_{2,4}=689 \\
\sum \mathrm{X}_{2,4}^{2}=15525 \\
\overline{\mathrm{X}}_{2,4}=22,00 \\
\mathrm{~s}_{2,4}^{2}=5,79\end{array}$ \\
\hline \multicolumn{2}{|c|}{ Total } & $\begin{array}{c}\mathrm{N}_{1,2}=38 \\
\sum \mathrm{P}_{1,2}=914 \\
\sum \mathrm{X}_{1,2}^{2}=22408 \\
\overline{\mathrm{X}}_{1,2}=23,97 \\
\mathrm{~s}^{2}{ }_{1,2}=11,58\end{array}$ & $\begin{array}{c}\mathrm{N}_{3,4}=36 \\
\sum \mathrm{P}_{3,4}=824 \\
\sum \mathrm{X}_{3,4}^{2}=19070 \\
\overline{\mathrm{X}}_{3,4}=22,88 \\
\mathrm{~s}_{3,4}^{2}=7,95\end{array}$ & $\begin{aligned} \mathrm{N}_{\mathrm{g}} & =74 \\
\sum \mathrm{P}_{\mathrm{g}} & =1738 \\
\sum \mathrm{X}_{\mathrm{g}}^{2} & =41478 \\
\overline{\mathrm{X}}_{\mathrm{g}} & =23,46 \\
\mathrm{~s}^{2} & =9,20\end{aligned}$ \\
\hline
\end{tabular}

Rangkuman data tersebut dapat dilihat pada Tabel 2 dengan menggunakan analisis deskriptif.

Tabel 2. Rangkuman Data Hasil Perhitungan Analisis Deskriptif.

Setelah data tabel 4.15 diolah dengan ANAVA 2 jalur faktorial 2 x 2, maka diperoleh hasil analisis seperti ditunjukkan pada Tabel 4.16.

Tabel 3. Ringkasan Perhitungan ANAVA Faktorial 2x2 


\begin{tabular}{|c|c|c|c|c|c|c|}
\hline Sumber Varians & JK & $\mathrm{dk}$ & KT & $F_{\text {hitung }}$ & \begin{tabular}{|c|}
$F_{\text {ta be } 1}$ \\
$(\alpha=0,05$
\end{tabular} & Ket. \\
\hline Model & 25,04 & 1 & 25,04 & 4,5 & \multirow{3}{*}{3,97} & Signifikan \\
\hline Gaya Berpikir & 84,79 & 1 & 84,79 & 15,22 & & Signifikan \\
\hline Interaksi & 158,77 & 1 & 158,77 & 28,5 & & Signifikan \\
\hline Dalam kelompok (galat) & 268,6 & 76 & 5,69 & & & \\
\hline Total & 839,9 & 79 & & & & \\
\hline
\end{tabular}

Perbedaan Hasil Belajar Bahasa Arab Antara siswa yang Diajar dengan Strategi Pembelajaran Komunikatif dan Struktural

Pengujian dilakukan terhadap hipotesis statistik yang dirumuskan sebagai berikut.

Но: $\quad \mu_{A 1}=\mu_{A 2}$

Ha : $\mu_{A 1}>\mu_{A 2}$

Dari hasil perhitungan analisis perbedaan hasil belajar bahasa Arab siswa yang diajar dengan strategi pembelajaran komunikatif sebesar $\overline{\mathrm{X}}=28,48$ dan strategi struktural $\bar{X}=27,46$ didapat harga $F_{h}$ sebesar 3,38 dan harga $F_{t}$ adalah 2,67. Karena $F_{h}$ $3,38>2,67$, maka Ho ditolak, hipotesis penelitian yang menyatakan: hasil belajar bahasa Arab siswa yang diajar dengan strategi pembelajaran komunikatif lebih tinggi daripada hasil hasil belajar bahasa Arab siswa yang diajar dengan strategi pembelajaran struktural pada taraf kepercayaan $\alpha=0,05$ teruji kebenarannya.

Perbedaan Hasil Belajar Bahasa Arab Antara Siswa dengan Siswa Dengan Komunikasi Interpersonal Tinggi dan Siswa Dengan Komunikasi Interpersonal Rendah.

Hipotesis yang dirumuskan berbentuk :

Ho: $\quad \mu_{B 1}=\mu_{B 2}$

Ha : $\mu_{B 1}>\mu_{B 2}$

Hasil perhitungan analisis varian tentang perbedaan hasil belajar bahasa Arab antara siswa yang memiliki dengan komunikasi interpersonal tinggi dan siswa dengan komunikasi interpersonal rendah dengan rata-rata $\bar{X}=29,00, \bar{X}=26,86$. Berdasarkan tabel 27 dapat dihitung $\mathrm{F}_{\mathrm{h}}=$ 22,74 dan harga tabel untuk $\alpha=0,05$ dengan dk (1:) diperoleh $\mathrm{F}=2,67$ sehingga dapat dinyatakan $F_{h}(22,74)>F_{t}(2,67)$. Dengan demikian Ho ditolak, hipotesis penelitian yang menyatakan: hasil belajar bahasa Arab siswa dengan komunikasi interpersonal tinggi lebih tinggi daripada hasil belajar siswa yang dengan komunikasi interpersonal rendah pada taraf kepercayaan $\alpha=0,05$ teruji kebenarannya.

Interaksi Antara Strategi Pembelajaran dan Komunikasi Interpersonal Terhadap Hasil Belajar Bahasa Arab

Pengujian dilakukan terhadap hipotesis statistik yang dirumuskan sebagai berikut :

Ho : interaksi $\mathrm{A} \times \mathrm{B}=0$

$\mathrm{Ha}$ : interaksi $\mathrm{A} \times \mathrm{B} \neq 0$

Berdasarkan rata-rata hasil belajar bahasa Arab untuk setiap kelompok pembelajaran yaitu, untuk strategi pembelajaran komunikatif pada siswa dengan komunikasi interpersonal tinggi $\bar{X}=30,18$, untuk strategi pembelajaran komunikatif pada siswa dengan komunikasi interpersonal rendah $\quad \bar{X}=26,64, \quad$ untuk strategi pembelajaran struktural pada siswa dengan komunikasi interpersonal tinggi $\overline{\mathrm{X}}=27,86$ dan untuk strategi pembelajaran Struktural pada siswa dengan komunikasi interpersonal rendah $\bar{X}=27,05$ hasil perhitungan ANAVA fatorial $2 \times 2$ diperoleh hasil perhitungan $F_{h}=29,62$ dengan harga tabel $F_{t}$ untuk taraf kepercayaan $(\alpha)$ sebesar 0,05 dengan $\mathrm{dk}=(3: 154)$ adalah $\mathrm{F}_{\mathrm{t}(0,05)}=2,67$ sehingga dapat dinyatakan $F_{h}(29,62)>F_{t}$ $(2,67)$. Dengan demikian Ho ditolak, hipotesis penelitian yang menyatakan terdapat interaksi antara strategi 
pembelajaran dan komunikasi interpersonal terhadap hasil belajar bahasa Arab teruji kebenarannya pada taraf signifikan 0,05 .

Data yang diperoleh dalam penelitian ini berasal dari sampel yang jumlahnya berbeda untuk setiap sel Anava. Sehingga perlu dilakukan uji Schefee, hasil pengujian dengan menggunakan uji Scheffee dapat dilihat dalam Tabel 4.17.

Tabel 4. Ringkasan Hasil Pengujian Dengan Menggunakan Uji Scheffe

\begin{tabular}{|l|l|l|l|l|l|}
\hline \multirow{2}{*}{ No } & \multicolumn{2}{|l}{ Hipotesis Statistik } & \multirow{2}{*}{ F $_{\text {hitung }}$} & F $_{\text {tabel }}$ \\
& & $\alpha=5 \%$ & $\alpha=1 \%$ \\
\hline 1 & Ho $: \mu_{1}=\mu_{3}$ & Ha $: \mu_{1}>\mu_{3}$ & $\mathbf{3 8 , 4 1}$ & $\mathbf{2 , 7 0}$ & $\mathbf{4 , 3 0}$ \\
\hline 2 & Ho $: \mu_{1}=\mu_{2}$ & Ha $: \mu_{1}>\mu_{2}$ & $\mathbf{2 7 , 5 4}$ & $\mathbf{2 , 7 0}$ & $\mathbf{4 , 3 0}$ \\
\hline $\mathbf{3}$ & Ho $: \mu_{1}=\mu_{4}$ & Ha $: \mu_{1}>\mu_{4}$ & $\mathbf{7 , 9 3}$ & $\mathbf{2 , 7 0}$ & $\mathbf{4 , 3 0}$ \\
\hline 4 & Ho $: \mu_{2}=\mu_{4}$ & Ha $: \mu_{2}>\mu_{4}$ & $\mathbf{4 , 7 3}$ & $\mathbf{2 , 7 0}$ & $\mathbf{4 , 3 0}$ \\
\hline $\mathbf{5}$ & Ho $: \mu_{3}=\mu_{4}$ & Ha $: \mu_{3}>\mu_{4}$ & $\mathbf{4 , 1 0}$ & $\mathbf{2 , 7 0}$ & $\mathbf{4 , 3 0}$ \\
\hline 6 & Ho $: \mu_{2}=\mu_{3}$ & Ha $: \mu_{2}>\mu_{3}$ & $\mathbf{2 , 8 5}$ & $\mathbf{2 , 7 0}$ & $\mathbf{4 , 3 0}$ \\
\hline
\end{tabular}

Interaksi antara model pembelajaran dengan gaya belajar tersebut dapat divisualisasikan dalam bentuk grafis pada gambar 1 .

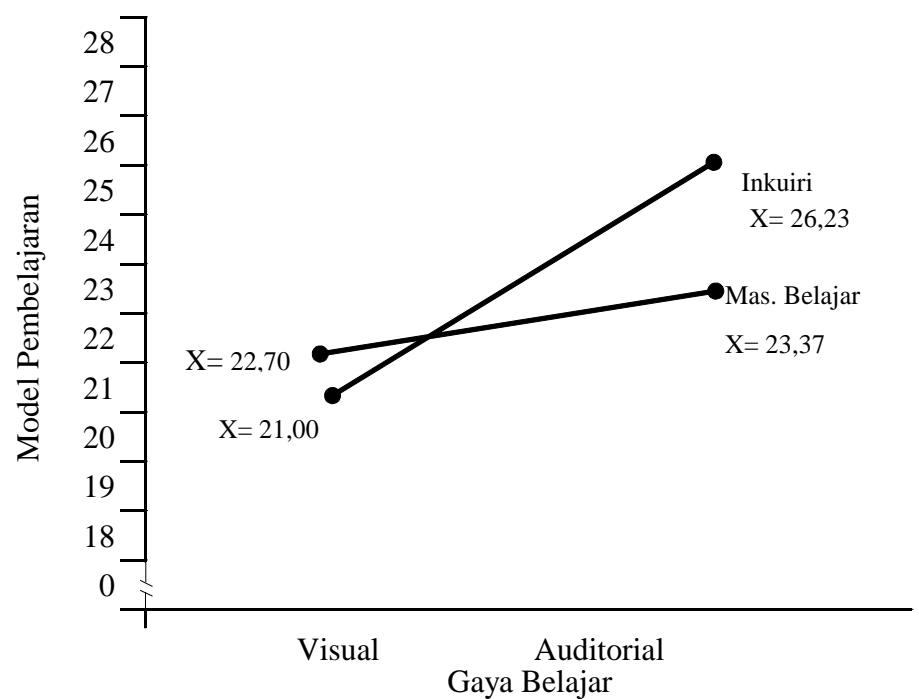

Gambar 1. Interaksi Model Pembelajaran dan Gaya Belajar terhadap Hasil Belajar

\section{PEMBAHASAN}

Hasil belajar bahasa Arab siswa yang diajarkan dengan strategi pembelajaran komunikatif lebih tinggi dibandingkan degan hasil belajar bahasa Arab siswa yang diajarkan dengan strategi Struktural, maka hal ini dapat dijadikan pertimbangan bagi guru yang mengajar pada mata pelajaran bahasa Arab untuk menggunakan strategi pembelajaran komunikatif dalam pembelajaran, khususnya pembelajaran bahasa Arab pada siswa MA.

Penggunaan strategi komunikatif dalam pembelajaran bahasa Arab berlangsung dengan penuh demokratis, aktif, dan alamiah antara guru dengan siswa secara bersama-sama dalam upaya mewujudkan bahan pembelajaran sesuai dengan situasi dunia nyata siswa. Peran guru dalam proses pembelajaran tersebut adalah sebagai fasilitator. Pembelajaran bahasa Arab dengan menggunakan strategi komunikatif, bukan bentuk bahasa ataupun pengahafalan bahan pembelajaran yang menjadi sorotan perhatian, akan tetapi penekanan strategi tersebut terletak pada bagaimana bahan pembelajaran yang disampaikan oleh guru dapat bermakna bagi kehidupan siswa, baik dari segi makna maupun fungsi bahasa sebagai alat komunikasi. Belajar bahasa dengan strategi komunikatif berarti belajar mengaitkan semua unsur dan struktur bahasa 
dengan makna karena bahasa adalah pengungkapan ide atau konsep. Pengajaran bahasa dengan strategi komunikatif lebih humanistik. Siswa ditempatkan pada posisi aktif sebagai pusat kegiatan pembelajaran.

Hal yang berbeda terjadi pada strategi struktural, yaitu proses pembelajaran sepenuhnya didominasi oleh guru. Guru lebih banyak memberi penjelasan terperinci dalam penerapan berbahasa, bukan melatih berbahasa nyata siswa. Belajar bahasa Arab dipandang sebagai perangkat fakta-fakta yang harus dihafal oleh siswa, karena pembelajaran berorientasi pada target penguasaan bahan pembelajaran sesuai dengan tuntutan kurikulum.

Dengan target penguasaan bahan pembelajaran seperti ini, terbukti siswa berhasil mengingat bahan pelajaran hanya dalam jangka waktu yang pendek, tetapi gagal membekali mereka agar mampu mengaplikasikan bahasa Arab dan mengingatnya dalam jangka waktu yang panjang di dunia nyata.

Hasil yang diperoleh dari penelitian ini dapat dijadikan bahan pertimbangan bagi guru untuk lebih aktif dalam menggunakan berbagai strategi dalam pembelajaran dan tidak hanya menggunakan satu strategi pembelajaran saja, namun disesuaikan pada karakteristik siswa dan karakteristik mata pelajaran.

Siswa yang dengan komunikasi interpersonal tinggi dan siswa dengan komunikasi interpersonal rendah memiliki perbedaan hasil belajar bahasa Arab pada strategi pembelajaran yang berbeda, dengan kegiatan pembelajaran yang bervariasi siswa yang memiliki perbedaan karakteristik fisik dan psikologis tertentu dapat terbantu dan meningkat hasil belajarnya sesuai dengan karakteristik yang dimilikinya. Hasil temuan ini menunjukkan bahwa karakteristik siswa turut serta mempengaruhi hasil belajar bahasa Arab siswa.

Untuk itu semua unsur pendidik yang terlibat dalam pendidikan di sekolah perlu dibekali pengetahuan mengidentifikasi pendekatan pembelajaran yang cocok dengan karakteristik tertentu yang dimiliki siswa.

\begin{tabular}{llrr} 
Dengan & \multicolumn{2}{c}{ menggunakan } & strategi \\
pembelajaran & yang & sesuai & dengan \\
karakteristitik & siswa & maka & kegiatan \\
pembelajaran akan lebih bermakna, & sehingga \\
pembelajaran yang dilaksanakan lebih
\end{tabular}

efektif, efesien dan memiliki daya tarik. Namun perlu disadari bahwa tidak ada suatu strategi pembelajaran yang sesuai untuk setiap karakteristik siswa maupun, karakteristik materi pembelajaran. Tetapi hasil penelitian ini bisa menjadi masukan bagi guru mata pelajaran bahasa Arab untuk memilih strategi pembelajaran yang sesuai dalam mengajarkan siswa di sekolah.

Sesuai dengan hasil penelitian, maka hendaknya guru dapat merancang kegiatan pembelajaran yang tepat dan sesuai dengan memperhatikan karakteristik siswa, yaitu siswa yang dengan komunikasi interpersonal tinggi dalam belajar bahasa Arab akan lebih tinggi hasil belajarnya jika diajarkan dengan strategi komunikatif. Dalam merancang pembelajaran dengan strategi komunikatif, perlu diperhatikan berbagai aspek pendukung kegiatan prosedur berkomunikasi, misalnya kesesuaian ketersediaan wacana dan keterampilan siswa dalam menggunakan bahasa secara tepat dan benar. Guru harus mampu memfasilitasi kebutuhan siswa dengan memunculkan komunikasi yang aktif dan sesuai, penggunaan bahan bacaan, wacana ataupun percakapan yang tepat menjadi stimulus bagi siswa untuk dapat terlibat aktif dalam setiap langkah pembelajaran dan sekaligus memperoleh pengetahuan yang bermanfaat dalam pembelajaran

Tujuan akhir pembelajaran bahasa Arab adalah mengharapkan siswa berkompeten dalam bidang bahasa Arab baik dalam kegiatan mendengarkan, membaca, berbicara, maupun menulis, oleh karena itu dalam penyampaian materi bahasa Arab ini membutuhkan pemahaman langsung pada diri siswa agar mereka memiliki motivasi, kemauan dan kemampuan dalam mengkomunikasikan bahasa secara tepat dan benarakelak setelah mereka menyelesaikan pendidikannya di sekolah. Oleh karenanya disarankan bagi guru untuk menggunakan strategi pembelajaran komunikatif dalam pembelajaran bahasa Arab agar hasil belajar bahasa Arab siswa tersebut lebih tinggi.

Untuk meningkatkan hasil belajar bahasa Arab siswa dengan komunikasi interpersonal tinggi, strategi pembelajaran komunikatif merupakan salah satu alternatif yang sesuai dengan karakteristik siswa tersebut, di samping itu dengan strategi ini siswa akan lebih terlatih dan terbiasa 
melakukan kegiatan yang berkaitan erat dengan mengkomunikasikan bahasa secara langsung. Melalui strategi komunikatif siswa terbiasa melakukan komunikasi yang erat kaitannya dengan konsep-konsep bahasa Arab, dengan seringnya siswa berkomunikasi secara langsung, maka akan terjadi perubahan sikap dan kemampuan keterampilan berbahasa pada diri siswa, dan hal ini secara tidak langsung dapat meningkatkan hasil belajar siswa.

Untuk pensosialisasian strategi pembelajaran Komunikatif, hendaknya dilakukan berbagai seminar ataupun pelatihan bagi guru-guru, agar strategi ini dapat dijadikan sebagai salah satu alternatif dalam menyampaikan materi pelajaran di sekolah pada tiap jenjang pendidikan.

\section{PENUTUP}

Berdasarkan hasil penelitian dan pembahasan yang dikemukakan sebelumnya, maka dapat simpulkan bahwa :

1. Hasil belajar bahasa Arab siswa yang diajar dengan strategi pembelajaran komunikatif lebih tinggi daripada hasil belajar bahasa Arab siswa yang diajar dengan strategi pembelajaran struktural.

2. Hasil belajar bahasa Arab siswa dengan komunikasi interpersonal tinggi lebih tinggi dari pada hasil belajar bahasa Arab siswa dengan komunikasi interpersonal rendah.

3. Terdapat interaksi antara strategi pembelajaran dan terhadap hasil belajar bahasa Arab siswa.

4. Berdasarkan uji lanjut diperoleh hasil bahwa siswa dengan komunikasi interpersonal tinggi jika diajar dengan strategi pembelajaran komunikatif memperolah hasil belajar bahasa Arab lebih tinggi daripada dengan siswa dengan komunikasi interpersonal tinggi yang diajar dengan strategi pembelajaran Struktural, dan hasil belajar bahasa Arab siswa dengan komunikasi interpersonal rendah yang diajar dengan strategi pembelajaran struktural lebih tinggi daripada siswa dengan komunikasi interpersonal rendah yang diajar dengan strategi pembelajaran komunikatif.

\section{DAFTAR PUSTAKA}

Anglin, G.J. (1991). Instructional Technologi, past, present, future.
Engelwood Colorado: Librarias Unlimited, Inc.

Anwar, S, dan Yusuf T. (1995). Metodologi Pengajaran Agama dan Bahasa Arab, Jakarta: PT. Raja Grafindo.

Arikunto, S. (2002). Dasar-dasar Evaluasi Pendidikan. Jakarta: Pustaka Pelajar

Bloom, B.S. (1985). Taxonomy of Educational Objectives. Handbook 1: Cognitive domain. New York: David McKay

Dahnia, L (2010) Hubungan antara Kemampuan Bilingual dengan Keterampilan Berkomunikasi Interpersonal Pada Siswa Kelas X SMAN 4 Semarang. Jurnal Penelitian. Malang: Universitas Negeri Malang. Vol 4, No,5.

Dahar, R.W. (1989). Teori-teori Belajar. Jakarta: Erlangga

Damanik, C. P. (2006). Pengaruh Pendekatan Pembelajaran dan Kemampuan Verbal Terhadap Hasil Belajar Bahasa Jerman Siswa SMAN 2 Medan. Tesis. Program Pascasarjana UNIMED.

Degeng. S.N.I. (1989). Ilmu Pengajaran Taksonomi Variabel. Jakarta: Proyek Pengembangan Lembaga Pendidikan Tenaga Kependidikan Departemen P dan K.

Departemen Agama. 2003. Kurikulum Pendidikan MA Silabus Bahasa Arab. Jakarta: Departemen Pendidikan Nasional

Devito, J.A. (2002). The Interpersonal Communication Reader. New York: Allyn and Bacon.

Dick, W. , Carey, L., and Carey, J.O. (2005). The Systematic Design of Instruction (Edisi II). USA: Scott, Foreman.

Farida, N. (2006) Hubungan Sikap Siswa Pada Pergaulan Teman Sebaya dan Komunikasi Antar Pribadi Terhadap Penguasaan diri Remaja di Kelas XI SMA Teuku Umar Tahun pelajaran 2004-2005. Jurnal Penelitian. Semarang: Universitas Negeri Malang

Gagne. (1979). Principles of Instructional Design, Second edition. New York: Holt Rinehart and Winston

Hornby. (1980). Oxford Advance Learner's Dictionary of Currenter English. London: Oxford University 
Joyce, B. dan Weil, M. (1996). Models of Teaching. Englewood Cliffs, New Jersey: Prentice -Hall Inc.

Kamaluddin. (2005). Inovasi Pembelajaran dalam PBM Bahasa Arab. Makalah Pelatihan Guru-guru Bahasa Arab oleh HMPS STAIN Batusangkar.

Kaseng, S. (1989). Linguistik Terapan: Pengantar Menuju Pengajaran Bahasa Yang Sukses. Jakarta: Deaprtemen Pendidikan dan Kebudayaan

Littelwood, W. (1983). Communicative Langunge Teaching and Instruction. London: Cambridge University Press.

Muhaiban. (2006). 'Al-lughah al-'Arabiyyah fi Indunisiya: Dirasah Ta'liliyyah 'an Tatawwuratiha wa Musykilat Ta'limiha'. Jurnal Studia Islamika UIN Sunan Kalijaga Yogyakarta, Vol. 13, No. 1

Muhammad (2004). Komunikasi Organisasi. Jakarta: Bumi Aksara.

Mulyana, D. (2002). Ilmu Komunikasi Suatu Pengantar. Bandung: Remaja Rosdakarya

Mulyasa. (2007). Menjadi Guru Profesional Menciptakan Pembelajaran yang Kreatif dan Menyenangkan. Bandung Remaja Rosdakarya.

Nababan. P.W.J. (1993). Metodologi Pembelajaran Bahasa. Jakarta: Gramedia Pustaka Utama

Nasution, S. (1991). Teknologi Pendidikan. Bandung: Jemmars

Nasution, A.S.A. (2006). Bunyi Bahasa. Jakarta: UIN Press

Nurhadi. (1995). Tata Bahasa Pendidikan Landasan Penyusunan Buku Pelajaran Bahasa. Semarang: IKIP Semarang Press

Nurhadi. (2004). Kurikulum 2004 Pertanyaan dan Jawaban. Jakarta: Grasindo

Purwo, .B. K. (1990). Pragmatik dan Pembelajaran Berbahasa Menyibak Kurikulum 1984. Yokyakarta: Kanisius

Rahmad, J. (2001) Psikologi Komunikasi. Bandung: Remaja Rosadakarya

Reigeluth, C.M. (1983). Instructional Design Theory of Pendekatans: An Overviuw of the their Current Status. London: Prentice Hall

Romizowski, A.Z. (1981). Designing Instructional System. New York: Nichol Publishing Company.
Rostiyasah (2001). Strategi Belajar Mengajar. Jakarta: Bina Aksara

Sadiman, A. M. (2003), Interaksi dan Motivasi Belajar Mengajar. Jakarta : Raja Grafindo Persada

Sadtono. (1987) Antologi Pembelajaran Bahasa Asing Khususnya Bahasa Inggris. Jakarta: P2LPTK

Sakholid. (2005). Analisis Konstraktif Bahasa Arab dan Bahasa Indonesia. Jakarta

Sanjaya, W. (2007). Strategi Pembelajaran Berorintasi Standar Proses Pendidikan. Jakarta: Kencana Prenada Media Group

Snellbecker, Glen E. (1974). Learning Theory Instructional Theory and Psychoeducational Design. New York: Me, Graww-Hill Inc.

Sudjana. (2002). Metode Statistika. Bandung: Tarsito.

Sugiyono. (2006). Metode Penelitian Pendidikan. Bandung: Alfabeta.

Sumarsono (2004) Buku Ajar Filsafat Bahasa. Jakarta: Grasido

Suprayekti. 2003. Interaksi Belajar Mengajar. Jakarta: Departemen pendidikan Nasional

Shell, B. C dan Richey, R.C. (1994). Instuctional Technology the Defenition and Domains of the Filed. Washington: terjemahan Yusuf Hadi Miarso, dkk.

Syah, M. (1999). Psikologi Belajar. Jakarta: Logos Wacana Ilmu

Suwarna. (2002). Strategi Penguasaan Berbahasa. Yokyakarta: Adicita

Tillaar, H.A.R. (2001). Manajemen Pendidikan Nasional Kajian Masa Depan. Bandung: Remaja Rosdakarya

West, R. dan Turner L.H. (2008). Pengantar Teori Komunikasi Analisis dan Aplikasi, Buku 1. Jakarta: Salamba Humanika.

Winkel. W.S. (2007). Psikologi Pengajaran. Yokyakarta: Media Abadi.

Yunus. (1999). Durus Al-Lugat al-Arabiah. Jakarta: Hidakarya Agung. 